\title{
UNDERSTANDING POWER: \\ BRINGING ABOUT STRATEGIC CHANGE
}

\author{
by \\ Cynthia Hardy \\ Faculty of Management \\ McGill University \\ 1001 Sherbrooke West \\ Montreal, Canada, H3A 1 G5 \\ Tel: (514) 398-4020 \\ Fax: (514) 398-3876
}

Published in British Journal of Management, 7 (Special Issue), 3-16, 1996 


\title{
UNDERSTANDING POWER: BRINGING ABOUT STRATEGIC CHANGE
}

\begin{abstract}
Success in today's competitive and complex world depends upon the ability to bring about effective strategic change. Much of the business literature has been preoccupied with finding more sophisticated techniques to formulate better strategies. But busines success depends not only finding the right strategy, but also ensuring it materializes in the form of a pattern of appropriate strategic actions. We know relatively little about this part of the strategy making process. This article shows how a better understanding and use of power can provide the energy to ensure strategic action by driving the organization and its members through the strategy making process.
\end{abstract}




\section{Introduction}

Success in today's competitive and complex world depends upon the ability to bring about broadsweeping strategic change. Unfortunately, our success in translating strategic intent into organizational action has been limited: and many North American and European companies find themselves struggling to put effective strategies into place. Success clearly depends then, not only upon finding creative, new strategies, but also on being able to realize them by making the necessary changes throughout the organization. Organizational members must be able to think and act strategically. The body of work on strategy-making has, however, tended to focus on the formation of strategic intent at the expense of its realization (Hurst, 1986; Huston, 1992). This paper argues that, instead of sidestepping the issue of implementation, we must directly confront it and, more specifically, we must examine the role that power plays in bringing about strategic action.

One problem with discussing power concerns its negative connotation -- power "over" someone else. Despite work on the advantages of using power, it is often seen as unethical and inappropriate to good management (Pfeffer, 1992). This conceptualization has driven researchers away from deeper study of political dynamics. To redress this tendency, power is deliberately defined here in neutral terms. It is a force that affects outcomes; while politics is power in action. These definitions allow us to study power "to": the productive side of power that allows us to achieve outcomes we could not achieve alone (Knights \& Morgan, 1991). 
[Power is the ability of] different parties to achieve something together they could not accomplish individually. This power governs a politics concerned with creating new possibilities in a world where resources may be scarce but some interests may be joined and new resources created. This is win-win politics: victory is only collective, and one party's loss defeats all (Baum, 1989: 195).

Power can, then, provide the energy for strategic change. Without it, we face strategic paralysis because we lack a mechanism with which to make change happen.

Political approaches to strategy-making are not new (e.g., Pettigrew, 1977; MacMillan, 1978; Narayanan \& Fahey, 1982; Gray \& Ariss, 1985; Schwenk, 1989) but, as will be argued here, they tend to promote an overly narrow conceptualization of power that focusses on only one aspect of power -- the mobilization of resources (e.g. funds, information, expertise, and credibility). This paper argues that power comprises a number of dimensions, of which resources is only one: it is also embedded in processes and meaning (Lukes, 1974: Hardy, 1994). By acknowledging the multidimensionality of power, managers can develop a broader array of mechanisms with which to ensure strategic action. Another weakness of traditional management approaches is that they tend to view power as being exercised solely in the face of conflict. While this may be of some use to managers facing overt resistance to strategic initiatives, it does not help those seeking to orchestrate collaborative action by preventing conflict over strategic options from emerging. So, given the lack of understanding in the mainstream management literature about power and apparent lack of success in implementing effective strategies, there seems to be scope for 
reconsidering power in a strategic context, and from a more sophisticated perspective (Hardy, 1995).

This article explores the problem of strategic action and shows how power can provide the energy needed to drive the organization and its members through the strategic change process. The following section recaps the various components of the strategy-making process. The paper then shows the importance of power to strategymaking and the deficiencies of other approaches to strategic change. A model is then presented that describes four dimensions of power that work for and against strategic change. Finally, we explore how managers can mobilize and target those power dimensions more effectively to achieve strategic action.

\section{Strategic Action: Realizing Strategic Intent}

Before we can discuss the process of strategic change, we need to clarify what is meant by the terms "strategy" and "strategic action." Definitions of strategy have been subject to great debate concerning whether it constitutes those actions which are planned or those which are realized (Mintzberg \& Waters, 1985). For the purposes of this paper, strategy is defined as the latter.

Strategy is realized in practice through consistency in a stream of actions and decisions over time (Pettigew, 1985: 438).

The actions in question concern the mobilization of organizational resources to exploit environmental opportunities and/or defend against threats (e.g., Andrew, 1980). The focus on actions, rather than plans, enables us to consider three situations: deliberate strategies where intentions are successfully realized; unarticulated, unintended emergent strategies; and unrealized strategies where intentions are not carried out 
(Mintzberg \& Waters, 1985). Strategic action refers to the first situation: the realization of deliberate strategy through the transformation of strategic intent into a pattern of actions that constitute an effective strategy.

This approach does not separate "formulation" from "implementation" but simply concentrates on the issues associated with the latter. The discussion of power means that it is impossible to separate formulation and implementation. First, the political issues raised here help to explain why formulation and implementation are interwoven, by showing how organizational members resist or influence strategic ideas. Second, the discussion helps to explain why managers often form their strategic ideas in response to the political realities that they face. Third, the focus on helping managers realize their intentions does not preclude the fact that the strategy may be modified, changed or even abandoned along the path to realization, even if management's aim is usually to reduce the likelihood of unrealized strategies. Nor does it deny that strategies can emerge in the absence of intent or develop incrementally as vague plans are refined in a step-by-step process.

In accordance with this definition, successful strategic action encompasses the realization of strategic intent through a process of organizational alignment. Strategic intent comprises the intentions of organizational members concerning the creation of a competitive advantage in the particular environment in which the business operates. The task of forging strategic intent has received considerable attention -- from Porter's categorization of cost leadership and differentiation, to strategic "stretch" (Hamel \& Prahalad, 1989; 1993; Prahalad \& Hamel, 1990) and strategic "thinking" (Pascale, 1990). While the more recent work redresses the mechanistic approach of the 
traditional planning literature, it does not tackle how the organizational changes necessary to support new strategic initiatives can be implemented. Strategic intent is thus only the first part of a much more complex process of which strategic realization is the goal. It is achieved only when modifications are made to structure, systems, human resource policies, and culture that align the organization with the desired stategy.

Successful strategy-making depends, then, upon some for of alignment of key design parameters which reconstitute the organization in a way that renders it capable of carrying out the strategy (e.g., Miles \& Snow, 1978; Peters \& Waterman, 1982). The starting point of alignment is, typically, structure, which has long been linked to strategy. More recently, traditional structures have been criticized for concentrating power in the hands of senior managers in a way that disenfranchises and alienates employees. Accordingly more flexible organizational forms have been advocated through empowerment, cross-functional teams, and increased participation in strategy-making to introduce new perspectives, increase motivation, and dismantle departmental barriers. The desire for flexibility has also permeated organizational boundaries between organizations in the form of joint ventures, strategic alliances, outsourcing, and the modular and virtual corporation.

Organizational structures depend upon systems to make them work. Systems comprise a number of different elements that together constitute both the glue, which holds holds the organization together, and the dynamism that enables them to react. Information systems are particularly important, especially with recent technological developments that have added to the ways in which information can be acquired, processed and disseminated. 
Another important constellation of design parameters concerns people. Human resource policies must ensure that people with the appropriate skills are hired, trained, evaluated, compensated, and motivated in ways consistent with strategic aspirations. Selection and recruitment, performance evaluation and appraisal, rewards and compensation, and training and development must all support the strategic thrust of the organization.

Organizational culture is another important strategic variable. The success of Japanese firms led to a search for ways of transplanting this culture into North America, and the 1980s were marked by an increasing interest in organizational culture. By focussing on symbols, rituals, and myths, academics and practitoners alike have sought ways to create cultures to harness members' commitment, values and loyalty to improve competitive advantage, performance and productivity.

One reason why strategic change often fails is because the organization is not appropriately aligned around the new strategic initiative. For example, CEOs talk about quality but continue to reward productivity; mission statements stress innovation, but procedures preclude risk taking; restructuring creates divisions but decision-making remains centralized at the corporate level. Unless plans and ideas are transformed into action, strategic intent falls into the realm of unrealized strategy. So, the process of alignment and the organizational changes it embodies are crucial to successful strategy making. The question that then arises is: what means do managers have for tackling this strategic challenge?

The Role of Power in Strategy Making 
The previous section has elaborated the key components of strategic action but has not considered how the organization moves from intent, through alignment, to realization. The tendency to present strategy-making as a rational, orderly process has conveyed the impression that it happens automatically. This is, however, unlikely to be the case since all aspects of the strategic change process have political consequences. The formation of strategic intent, for example, is rarely a straightforward revelation of the "optimal" strategy but, instead, depends on the persuasion of other individuals on the basis of tenuous or ambiguous data, and possibly against their better judgement and personal interests. Different managers often have quite different ideas of what the organization's strategy is (Bowman \& Johnson, 1992; Floyd \& Wooldridge, 1992), let alone what it should be. Such disagreement should come as no surprise -- strategic change is complex, and ideas concerning the correct answer are bound to vary: what one individual sees as strategic salvation, another may dismiss as another crazy idea!

The work on alignment has also tended to ignore the political implications of organizational change. Structure is usually presented in clinical terms even though structural reorganizations inevitably involve more resources for some managers and less for others. Even the advantages of new organizational forms do not come without a price. Managers must learn to work across and dismantle, departmental boundaries. And if managers cannot break down these barriers, how can they expect to work across interorganizational boundaries, particularly when they traverse international frontiers, and link companies in alliances that span the world? Changes to information systems often fail because designers concentrate on technical issues, and forget about the users. More decentralized systems needed to support new organizational forms by allowiing 
employees throughout the organization access to strategic information and decisions may be resisted by senior managers who fear a loss of control.

Human considerations undoubtedly contribute to the success or failure of strategymaking: it is not enough simply to tell employees what the new strategy is. Unless the total sum of their experience converges in the same direction, strategic initiatives will be frustrated. But the relatively recent addition of human resource management to the strategic agenda (Fulmer, 1989) means that the human factors that provoke conflict have been conveniently left out of the strategic equation. Similarly, culture is often presented a neutral tool instead of the product of an intensely political process. A culture is formed, not by a few élite members of the organization pressing the right buttons, but as the result of a complex interactive process involving all members. Moreover, a "strong" culture, as recent events in IBM bear witness, can inhibit change. The stronger the culture, the more consistent the filtering process as people interpret information according to accepted norms and values, the more convergent the behaviour, and the more difficult it becomes to perceive, let alone act on, the need for radical change.

So, both the substance of strategic intent and the nature of strategic alignment have political implications, and managers may need power to confront resistance. Even in situations where employees support strategic change, power will still be necessary. The costs and benefits of major change are often hard to assess, rendering the rationalscientific paradigm unhelpful. "Without perfect, unbounded, rationality it is quite feasible that individuals and groups may agree on ends without agreeing on how they are to be pursued" (Walsh et al, 1981: 141). Accordingly, the actions that are crucial to the realization of strategic goals do not just "happen" -- power is needed to orchestrate and 
direct them. Hence power is an integral part of strategic change, regardless of whether the organization is a political cauldron of conflicting interests and power is a way to combat resistance to strategic intentions; or whether it is united by common goals and power is required to facilitate collaborative action.

To be able to use power for strategic action, managers must have a thorough understanding of what it involves. Mainstream management theory is of limited help in this regard because it has promulgated a particularly narrow view of power: one that is restricted to the mobilization of resource dependencies and to defensive manoeuvres undertaken in response to conflict. Here, we present a model that encompasses the dimensions of power (Lukes, 1974), derived from resources, processes and meaning (table 1), that can be used to combat the power embedded in the system to influence strategy-making processes in ways that help prevent opposition to strategic change..

- Table 1 near here -

\section{The First Dimension: the power of resources}

Lukes (1974) linked the first dimension of power to early studies of community power, which had focused exclusively on the decision-making process. These researchers had analyzed key decisions that seemed likely to illustrate the power relations prevailing in a particular community. The object was to determine who made these decisions. If the same groups were responsible, the community could be said to be ruled by an élite. The researchers found, instead, that different groups prevailed in decision making. They labelled such communities as "pluralist" and hypothesized that America as a whole was a pluralist society. This work assumed that power was only 
exercised in key decisions where conflict was clearly observable. Individuals were aware of their grievances and acted on them by participating in decision-making and using power to influence outcomes. Since the decision-making arena was considered to be open to everyone, the absence of participation indicated that actors agreed with decisions.

Lukes did not explicitly consider the managerial literature on power but the mainstream approach fits under this first dimension. Mainstream management studies have generally considered power to be the ability to get others to do what you want them to, if necessary against their will. This body of work has concentrated primarily on the link between power and the control of scarce resources used to influence behaviour in the face of resistance and opposition. Early studies (e.g.,Thompson, 1956; Mechanic, 1962; Crozier, 1964; Hickson et al, 1971; Pettigrew, 1973; Pfeffer \& Salancik, 1974) examined the link between power and the control of scarce resources. In this way, the management literature helps identify the bases of power that help actors influence decision making processes and defeat opposition (e.g., Pettigrew, 1973; Pfeffer, 1981).

According to this relatively common conceptualization, power is exercised by actors to influence decision outcomes and bring about the desired behaviour through the deployment of key resources on which others depend, such as information, expertise, political access, credibility, stature and prestige, access to higher echelon members, the control of money, rewards and sanctions. This form of power works along the lines of behaviour modification. It has, as a result, a limited impact since it is task-oriented and the continual deployment of either the carrot or stick may be necessary to ensure that the 
desired behaviour is sustained. Moreover, the excessive use of coercion may engender a backlash in the people over whom power is exercised.

\section{The Second Dimension: the power of processes}

The second dimension of power was developed as researchers began to criticize the assumptions underlying the work of the pluralists. Bachrach \& Baratz (1962) questioned whether decision-making processes were accessible to everyone; and whether nonparticipation really reflected genuine satisfaction. They criticized the pluralists for their failure to recognize that interests and grievances might not be articulated, remaining outside the formal decision-making arena, and argued that conflict could exist even if it was not directly observable. By examining the ways in which full-and-equal participation was constrained, Bachrach and Baratz uncovered processes whereby issues are excluded from decision making and the agenda is confined to "safe" questions.

This form of power resides in organizational decision making processes which incorporate a variety of procedures and political routines that can be invoked by dominant groups to influence outcomes by preventing subordinates from participating fully in decision-making. It has been termed nondecision making, because it allows the more powerful actors to determine outcomes from behind the scenes through the use of procedures and political routines. It highlights the fact that power is not exercised solely in the making of key decisions and that the most visible decision makers are not necessarily the most powerful.

Nondecision making has typically been seen as a device used by dominant groups to protect the status quo by mobilizing the biases that are embedded in existing decision making processes. It can, however, It can, however, also be used to bring about change, 
by extending access to decision making arenas and agendas (Hardy and Redivo, 1994). So, for example, new committees may be set up with new mandates and membership to bring change on to the agenda, incorporate new viewpoints, and raise awareness. While this dimension of power can produce more generalized and long-term changes than resource power, only behaviour consistent with the norms and values of the underlying system will endure. If the new behaviour clashes with underlying norms and values, it will probably fail (Hardy \& Redivo, 1994)

\section{The Third Dimension: the power of meaning}

Lukes developed a third dimension of power because he felt that Bachrach and Baratz's work did not go far enough. It continued to assume that some manifestation of conflict was necessary to stimulate the use of nondecision making power. By specifying the existence of conflict as a prerequisite of nondecision making, he argued that Bachrach and Baratz had overlooked the possibility that power might be used to prevent conflict from emerging in the first place. Lukes argued that power is often used to shape perceptions, cognitions, and preferences so that individuals accept the status quo because they cannot imagine any alternative. According to this view, the study of power cannot be confined to observable conflict, to the outcomes of decisions, or even to suppressed issues. It must also consider the question of political quiescence.

Initially, the third dimension of power was related to societal and class mechanisms which were deemed to perpetuate the status quo, but writers began to point out that it also occurred within the context of struggles at the local level (e.g., Giddens, 1979; Ranson et al, 1980; Clegg, 1989). Writers explored a similar conceptualization of power in a variety of different arenas including industrial relations (e.g. Fox, 1973; Hyman 
\& Fryer, 1975); labour process theory (e.g. Burawoy, 1979); political campaigns (Edelman, 1971; 1977); planning (Forester, 1989).

In the context of management, Pettigrew (1979) showed how interest groups legitimized their demands and "de-legitimized" the demands of others through the management of meaning (also see Clegg, 1975; Chaffee, 1985; Frost, 1987; Frost \& Egri, 1989). A study of factory closures found that managers who wanted to avoid union and employee resistance engaged in a complex strategy to legitimate the managerial decision to close the unit in question. It involved using symbols, such as redundancy (severance) compensation and consultation to emphasize managerial credibility and goodwill; and economic reports and presentations of the reasons behind the closure to justify it. In this way, the desired strategy was imbued with meaning -- as legitimate, rational, desirable or (failing that) unavoidable.These actions were symbolic, however, since consultation did not involve the closure decision; severance payments did not compensate for lost jobs; reports justifying the closure were based on confidential figures never made public; and the reasons given for the closures, although seductive, were not the real ones (Hardy, 1985). This dimension of power is probably the most sophisticated, and certainly the most broadsweeping. But, while it may lead to fundamental changes, it is difficult to target specific and precise changes in behaviour with it.

\section{The Fourth Dimension: the power of the system}

Finally, we must not ignore the power embedded deep within the organizational system that everyone takes for granted. This power is often beyond the reach of tampering by organizational members. It lies in the unconscious acceptance of the values, traditions, cultures, and structures of a given institution and it captures all 
organizational members in its web. Since it advantages or disadvantages individuals without being consciously mobilized, even those who profit from it find it difficult to change. This power is the backdrop against which all organizational actions and decisions takes place. Since it is vested in the status quo, it is unlikely to lead to change in the absence of any countervailing power (see Deetz, 1992; Knights, 1992). It is against this dimension of power that managers must employ the other three dimensions if they are to bring about strategic action.

The work of Foucault (e.g. 1979; 1980, 1982) emphasizes the power of the system and the degree to which all individual are limited in resisting, much less transforming this system (e.g. see Clegg, 1989; Knights \& Morgan, 1991). Nonetheless, this article argues that managers (and others) have some scope in modifying the power embedded in their organizations. It may not represent a transformational change and it certainly does not constitute an escape from the effects of power but, by effectively mobilizing and targetting the power of resources, processes and meaning, managers may be able to bring about strategic change.

\section{Mobilizing Power for Strategic Action: An Example}

Strategic change does not, then, occur in a vacuum: it takes place in a system in which a certain distribution of power is already entrenched. When managers attempt strategic change, they must use the first three dimensions of power to modify those parts of the existing system that inhibit the new behaviour necessary to support their initiatives. Strategic action typically hinges on the mobilization of all three dimensions. Relying solely on resources to reinforce the desired behaviour and/or punish unwanted behaviour is too task-oriented: organizational members will carry out the desired behaviour only with the 
continual deployment of the necessary resources. It will not sustain the long term change necessary to realize a new strategy. Process power facilitates behaviour in a way that does not rely on continual reinforcement by raising awareness. It is also limited, however, because only those changes that conform to existing norms and values will endure. Consequently, process power is insufficient to prevent the marginalization of the countercultural changes that are often integral to successful strategic change. By managing meaning, managers can change underlying values and norms but, used alone, its inability to target specific behaviour will hinder effective strategic change. By developing an integrated strategy, however, that draws on all three dimensions of power in a coordinated way, managers can bring about strategic change. Consider the following example drawn from Westley (1990). ${ }^{1}$

In response to foreign competition, the headquarters of Automakers Ltd, a US automobile manufacturer, decided to introduce a new strategy based on quality. As a result of this initiative, the manager of a Canadian manufacturing plant hired a group of consultants to implement a change program at managerial levels. Initial findings confirmed that managers wanted a change in the plant's culture, which focused on aggressive, autocratic management and emphasized inter-shift competition and, in the words of the managers themselves, "lying, cheating, and stealing". This culture had proven ineffective in meeting the challenges of foreign competition and was widely recognized as being out of step with the larger society. While both managers and consultants agreed that some for of change was necessary, their unspoken assumptions were very different. Management wanted to concentrate on improving quality and 
reducing costs; while the consultants wanted to change the culture by introducing a participative management style, which would improve quality as a by-product.

The consultants began to implement their change program by setting up management committees to engage in collective, participative decision making. By bringing managers together and providing a forum where they could learn new problem-solving techniques, the consultants hoped to effect a fundamental change in the underlying norms and values at the plant. They expected the managers to adopt the role of student while learning and experimenting with these new methods. The managers on the other hand, had a hard time making the connection between these new decision making methods and improving quality, particularly since the old pressures continued to haunt them. They were given no extra time to learn new ways of managing; productivity remained the main criterion of success; new behaviour was not rewarded; and when problems arose, individuals quickly reverted to the old management style. As a result, after two years of meetings, no change had been effected.

The reason for the failure was the following (see table 2). The consultants wanted to change the underlying system, but they used only the power of process -- the participative committees -- to do so. While this use of process power increased awareness of a new style of management, it had limited impact because it clashed with the managers' aggressive, macho values. Most of the time, particularly under the pressure of work, managers resorted to the behaviour they knew best. Senior managers also wanted change but their emphasis was on changing behaviour -- improving quality while maintaining productivity in order to comply with the directives from Detroit. They had little interest in more fundamental change and were confused by the consultants' use of 
process power -- they couldn't see how the participative committees would achieve their goals. They also ran into problems because they did not use resource power to bring about the specific behavioural changes they sought since the new behaviour was not rewarded and the old behaviour was not penalized.

- Table 2 near here -

The desired new strategy only came about at Automakers much later when, gradually, a few respected managers started to adopt the new management style. One particular manager finally comprehended what the consultants were trying to achieve and identified the skills that his subordinates needed to make sense of the new management style. He was able to act as bridge between the consultants and other managers, passing on what he learned and providing feedback. Another important individual, well known for being tough manager, was sceptical of the new management style but his loyalty to the company was such that he obeyed the orders to change management style. Unlike his colleague he did not fully understand the consultants' aims, but by his example, he convinced his subordinates that it was safe to act in accordance with the dictates of the program. When his subordinates showed a marked improvement both in productivity and morale, it provided an added impetus for the change.

These managers helped to change the meaning of a "good" manager -- from one who was macho, aggressive and punitive to one who was democratic and participative. Their actions were reinforced by the deployment of resources to reward quality, as well as managers who adopted and persevered with the new management style. The processes set up by the consultants continued to facilitate participative decision making. In other 
words, when the power of resources, processes, and meaning converged, the desired strategic change was achieved (table 3).

- Table 3 near here -

By managing meaning, process and resources, managers can redefine the strategic initiative, and the changes on which it hinges, as legitimate; create a new awareness through new processes; and control behaviour more directly with the specific deployment of resources. Mobilizing power for strategic action thus involves a coordinated approach that encompasses all three dimensions to influence actions, awareness and values, and avoid both inertia and confusion (table 4).

- Table 4 near here -

\section{Targeting Power for Strategic Action: An Example}

The previous example shows how power can be mobilized to release energy and drive strategic change. But strategic action depends on more than the release of energy; energy must also be channelled towards the appropriate alignment of the organizational parameters that underpin the new strategy. Accordingly, this section discusses how power can be targeted at structure, systems, people, and culture to enable the organization to carry out the strategic initiative. Consider the following example drawn from Roberts (1990). ${ }^{2}$

The Electric Light Bulb Company (ELB) had revenues of $£ 172$ million with factories in the UK and overseas. There were five factories in the UK as well as some specialized units which employed some 6,000 people. Factory managers were separated from the CEO by five hierarchical levels. Headquarters management exercized a strong, centralized control over the factories. ELB enjoyed a near monopoly in the UK and had 
been very profitable. This market dominance allowed cost increases to be passed on to customer, and the emphasis was on high volume production, regardless of cost. During the 1970s, competition increased and profits began to decline. In 1979, ELB was acquired by a large conglomerate, Conglom Inc, that sold off the overseas operations, leaving ELB to defend a shrinking UK market.

The new CEO of ELB decided that increased advertising would help slow down the decline. The problem was: how was ELB to fund an expensive advertising strategy that would not increase sales but only slow down the decline? Conglom was not prepared to provide the necessary injection of $£ 5$ million and, so, the CEO decided to reorganize ELB to cut costs ahead of the decline in volume and thus release funding internally. To do so, he made each factory a separate profit centre selling to a reorganized trading division. The factory managers, who previously had been separated from central management by several layers of hierarchy, became Factory Directors reporting directly to the CEO. Strict performance criteria were developed which required managers to hold costs constant despite decling sales -- any factory failing to meet them ran the risk of being rationalized and its operations folded into another, more successful factory.

The CEO also needed to find a centralizing force, however, otherwise the creation of strong local teams in the individual factories would jeopardize the overall performance of ELB. To offset the centrifugal forces of the decentralization, the CEO organized an annual conference where factory managers and other senior managers reported to managers from headquarters and other factories on their results for the past year and their plans for the coming year. The conference was preceded with a tour of the factories by the CEO, followed by a two-day pre-conference meeting of the managers who would 
be presenting. Having agreed on the outline for the main conference, the managers returned to their jobs and began to work on their individual presentations with their subordinates. A three-day rehearsal preceded the conference. These meetings helped to form an integrated, collective picture of ELB to which all managers subscribed. This corporate identity helped mitigate the excesses of the move to strong, local autonomy.

As a result of his actions, the CEO was able to reduce the number of employees from 6,000 to 1,600 with little or no resistance from managers. Over six years, ELB's return on capital employed rose from twelve percent to over 100 percent; profits doubled from $£ 18$ million to $£ 37$ million on reduced sales.

ELB represents a situation in which a new strategy demands the creation of both automous, decentralized units and a corporate identity and common vision. To realize the new strategy, the CEO made changes to the four components of alignment by mobilizing and targeting the three dimensions of power (table 5). To decentralize the structure, resources were withdrawn as five management levels were cut; process power was used in changing the reporting relationships; and meaning was managed through the designation of factory "directors" which served to symbolize their increased responsibilities. Resources were devoted to the development of new accounting systems. By bringing the payroll clerks into the process of designing the new systems, those closest to the data were brought on board and, by elevating their status, the importance of the new performance measures was underlined. The empowerment of factory managers was achieved through the threat of rationalization as the penality for failure, and by putting them in charge of the decision making arena at the factory level. The new meaning of their mandate of cost cutting was symbolized through the presentation of their 
results to other managers. Finally, a new corporate culture was fostered through the linking of bonuses to corporate performance, coopting factory directors into the firm's strategy-making process; and the CEO's visits to the individual factories symbolized the "company".

- Table 5 near here -

The example ELB shows how power must be mobilized and targeted. We know that the aim of strategic action is to change the "system," but it is such a broad concept that it is not terribly helpful to managers. Moreover, the system is resistant to change and it is not feasible to dismantle the whole material and cultural infrastructure of an organization. Even if it were, managers would run the risk of "throwing the baby out with the bathwater" since the system is also the repository of organizational learning, accumulated knowledge, individual wisdom and core competencies that cannot and should not be totally obliterated in the pursuit of change. By targeting the three dimensions of power towards the key components of strategic alignment, however, managers are much better placed to ensure strategic action. While this example breaks the actions down in order to enable readers to make more sense of them, it is important to note that the actions taken by ELB's CEO represent a coordinated, integrated strategy where the mobilization and targeting of power reinforce each other.

\section{Conclusions}

This paper argues that compared to the formation of strategic intent, we know very little about how to ensure strategic action by translating intentions into reality. Accordingly, there are very few strategy implementation models compared to the plethora of approaches available for strategy formulation. Models to help managers transform 
strategic intentions into reality can be broken down into three broad categories: the grand plan, the great man and the quick fix; and all have limitations.

The grand plan encompasses our obsession with conceiving strategy, but not realizing it. In the last five years, over 27,000 articles on strategy have been written, but only 110 on strategic change, according to a CD-Rom search of ABI-Inform abstracts between January 1989 and May, 1993. At least 30 different planning tools exist, with such exotic names as nominal group technique, dialectic inquiry, and metagame analysis, but less than a third give any consideration to the actions required to put the plan into practice (Webster et al, 1989). As a result, estimates suggest that less than ten percent of strategic plans are implemented (Kiechel, 1982; also see Hrebiniak, 1990; Mintzberg, 1993, 1994).

So, while business leaders are demanding a greater capacity for strategic action, the business literature remains largely preoccupied with strategic planning, and offers little help in forging organizations capable of capitalizing on opportunities in a sustained and profitable way. The idea seems to be that if only we could find the right strategy, we could ensure competitive success. Yet with such a gap in our understanding of implementation, it seems plausible to suggest that business success might be enhanced, not only by finding the right strategy, but also by ensuring that it actually materializes in the form of a pattern of appropriate actions.

The great man approach to strategy-making relates to the infatuation of the western world with "leadership". Particularly in times of crisis, charismatic figure (usually men), such as Lee laccoca, John Sculley, and Jack Welch, are brought in to save the organization. While there may be times when great leaders can be found, there are other 
times when there is an unfortunate dearth of visionaries. Moreover, the work on leadership glosses over much of the strategic task. It simplifies the process to: find a great leader with both charisma and vision; and use the charisma to implement the vision! It is the artist's counterpoint to the science of strategic planning; but it makes the same mistakes by glossing over the myriad of less visible actions that leaders take to contribute to strategic action -- charisma and vision are only part of the story. If the obsession with the grand plan has focused attention on formulation and ignored implementation, the leadership myth mystifies both formulation and implementation.

The quick fix refers to the dazzling array of techniques used in attempts to increase competitiveness. Unfortunately, many have failed to live up to expectations. For example, critiques argue that Total Quality Management focusses attention on internal processes at the expense of markets, customers and results; and leads to cumbersome bureaucracies that increase costs and response times, rather than reducing them (Chang, 1993; Harari, 1993; Kordupleski, 1993). Employee Empowerment has often missed the mark because managers have been reluctant to give away sufficient power to their subordinates and, instead, have used it to increase workloads while restricting career opportunities (Kizilos, 1990; Kaplan, 1991; Brown, 1992). Re-engineering has come under fire for promising over-optimistic cost savings have little chance of being realized (1993). According to Eccles \& Nohria (1993), many of these so-called solutions are, in fact, last year's failures: calls for empowerment mirror demands for employee participation made in the 1950-60s; the network organization can be traced back to Burns \& Stalker's organic form of organization in the 1960s; the trans-national organization is a global reprise of the matrix structure; and the need for decentralization was the subject of 
a twelve part series in Fortune as early as 1955. In other words, the quick fix has limited longevity.

This paper argues that a fourth approach is worth considering: power. The strategy-making literature avoids this topic, probably because of the discomfort that this term engenders. Experienced managers know that organizational reality paints a political picture, but rarely seem willing to admit it. Similarly, the research on the political nature of strategy-making is not incorporated into prescriptive literature which retains a firmly rational stance. The aversion to discussing power has restricted our understanding of it and impeded effective strategic change. Academics can contribute by exploring power and showing how it is part of the strategy making process.

Academics also have another role to play through their critique of the way in which management uses power. The model presented here is obviously directed at managers on the grounds that they are a legitimate constituency (Nord \& Jermier, 1992). It does not deny that in helping managers to understand power, it may lead them to use it in more sophisticated and less visible ways, which leaves employees particularly vulnerable to the abuse of power, particularly as meaning is managed and political issues are obscured. Mainstream management research tends to ignore questions of ethics and values that may be involved in such actions and simply to assume that the individuals should defer to the organizational imperatives (Scott \& Hart, 1979). By putting power back into the equation, however, the political dynamics of management are made visible and awareness can be raised concerning exactly how power is used. In this way, employees and other interest groups might also learn how to use power to protect their interests. Pretending that power does not exist, does not make it go away. 

Table 1

Three Dimensions of Power

\begin{tabular}{|c|c|c|c|}
\hline & $\begin{array}{l}\text { POWER OF } \\
\text { RESOURCES }\end{array}$ & $\begin{array}{l}\text { POWER OF } \\
\text { PROCESSES }\end{array}$ & $\begin{array}{l}\text { POWER OF } \\
\text { MEANING }\end{array}$ \\
\hline $\begin{array}{l}\text { SOURCE } \\
\text { OF } \\
\text { POWER }\end{array}$ & $\begin{array}{l}\text { ability to hire \& fire, } \\
\text { rewards, } \\
\text { punishments, } \\
\text { funding, authority, } \\
\text { expertise, etc. }\end{array}$ & $\begin{array}{l}\text { decision making } \\
\text { processes, } \\
\text { participants and } \\
\text { agendas, etc. }\end{array}$ & $\begin{array}{l}\text { symbols, rituals, } \\
\text { language, etc. }\end{array}$ \\
\hline $\begin{array}{l}\text { ACTION OF } \\
\text { POWER }\end{array}$ & $\begin{array}{l}\text { principles of } \\
\text { behaviour } \\
\text { modification are } \\
\text { used to influence } \\
\text { specific actions }\end{array}$ & $\begin{array}{l}\text { new awareness is } \\
\text { created by opening } \\
\text { up processes to } \\
\text { new participants, } \\
\text { issues and } \\
\text { agendas }\end{array}$ & $\begin{array}{l}\text { change is given } \\
\text { new meaning, } \\
\text { making it appear } \\
\text { legitimate, } \\
\text { desirable, rational } \\
\text { or inevitable }\end{array}$ \\
\hline $\begin{array}{l}\text { LIMITS TO } \\
\text { POWER }\end{array}$ & $\begin{array}{l}\text { continual use of } \\
\text { "carrot" or "stick" is } \\
\text { required to ensure } \\
\text { continued change; } \\
\text { repeated use of the } \\
\text { "stick" may be } \\
\text { counter-productive }\end{array}$ & $\begin{array}{l}\text { new awareness } \\
\text { helps sustain new } \\
\text { behaviour as long } \\
\text { as it remains within } \\
\text { existing values and } \\
\text { norms }\end{array}$ & $\begin{array}{l}\text { change in some } \\
\text { underlying values } \\
\text { and norms may be } \\
\text { possible but } \\
\text { specific changes in } \\
\text { behaviour will be } \\
\text { difficult to effect. }\end{array}$ \\
\hline
\end{tabular}


Table 2

Power at Automakers: Failure

\begin{tabular}{|c|c|c|c|}
\hline & $\begin{array}{l}\text { POWER OF } \\
\text { RESOURCES }\end{array}$ & $\begin{array}{l}\text { POWER OF } \\
\text { PROCESSES }\end{array}$ & $\begin{array}{l}\text { POWER OF } \\
\text { MEANING }\end{array}$ \\
\hline $\begin{array}{l}\text { IMPACT ON } \\
\text { ACTIONS } \\
\text { primary goal of } \\
\text { managers }\end{array}$ & $\begin{array}{l}\text { failure to deploy } \\
\text { power of resources } \\
\text { meant no reward } \\
\text { for new behaviour } \\
\text { (quality/ } \\
\text { management } \\
\text { style); nor sanction } \\
\text { for old behaviour } \\
\text { (macho style) }\end{array}$ & $\begin{array}{l}\text { managers were } \\
\text { confused about } \\
\text { the link between } \\
\text { the new } \\
\text { committees and } \\
\text { quality: they } \\
\text { could not see } \\
\text { how one would } \\
\text { lead to the other }\end{array}$ & not applicable \\
\hline $\begin{array}{l}\text { IMPACT ON } \\
\text { AWARENESS }\end{array}$ & not applicable & $\begin{array}{l}\text { awareness of a } \\
\text { different } \\
\text { management } \\
\text { style was created } \\
\text { by the } \\
\text { introduction of } \\
\text { new processes } \\
\text { (management } \\
\text { committees) but } \\
\text { the behaviour } \\
\text { clashed the } \\
\text { macho values of } \\
\text { the managers }\end{array}$ & not applicable \\
\hline $\begin{array}{l}\text { IMPACT ON } \\
\text { VALUES } \\
\text { primary goal of } \\
\text { consultants }\end{array}$ & not applicable & $\begin{array}{l}\text { the committees } \\
\text { were insufficient } \\
\text { to change } \\
\text { underlying values } \\
\text { concerning the } \\
\text { benefits of the } \\
\text { prevailing tough, } \\
\text { aggressive, } \\
\text { macho } \\
\text { management } \\
\text { style }\end{array}$ & $\begin{array}{l}\text { failure to use } \\
\text { power of meaning } \\
\text { meant no change } \\
\text { to underlying } \\
\text { values regarding } \\
\text { the definition of } \\
\text { good management }\end{array}$ \\
\hline
\end{tabular}


Table 3

Power at Automakers: Success

\begin{tabular}{|c|c|c|c|}
\hline & $\begin{array}{l}\text { POWER OF } \\
\text { RESOURCES }\end{array}$ & $\begin{array}{l}\text { POWER OF } \\
\text { PROCESSES }\end{array}$ & $\begin{array}{l}\text { POWER OF } \\
\text { MEANING }\end{array}$ \\
\hline $\begin{array}{l}\text { IMPACT ON } \\
\text { ACTIONS }\end{array}$ & $\begin{array}{l}\text { principles of } \\
\text { behaviour } \\
\text { modification are } \\
\text { used to influence } \\
\text { specific actions } \\
\text { EVENTUAL USE OF } \\
\text { RESOURCES } \\
\text { POWER } \\
\text { INFLUENCES } \\
\text { APPROPRIATE } \\
\text { BEHAVIOUR }\end{array}$ & not applicable & not applicable \\
\hline $\begin{array}{l}\text { IMPACT ON } \\
\text { AWARENESS }\end{array}$ & not applicable & $\begin{array}{l}\text { new awareness is } \\
\text { created through the } \\
\text { introduction of new } \\
\text { participants, } \\
\text { agendas and } \\
\text { processes } \\
\text { CONTINUED USE OF } \\
\text { PROCESS POWER } \\
\text { VIA COMMITTEE } \\
\text { STRUCTURE } \\
\text { REINFORCES } \\
\text { AWARENESS OF } \\
\text { NEW WAYS OF } \\
\text { MANAGING }\end{array}$ & not applicable \\
\hline IMPACT ON VALUES & not applicable & not applicable & $\begin{array}{l}\text { strategic change is } \\
\text { legitimated (given } \\
\text { new meaning) by } \\
\text { influencing values } \\
\text { and norms } \\
\text { EVENTUAL USE OF } \\
\text { MEANING POWER } \\
\text { REDEFINES GOOD } \\
\text { MANAGEMENT, } \\
\text { HELPING TO } \\
\text { CHANGE } \\
\text { UNDERLYING } \\
\text { VALUES AND } \\
\text { NORMS }\end{array}$ \\
\hline
\end{tabular}


Table 4

Mobilizing the Dimensions of Power

\begin{tabular}{|c|c|c|c|}
\hline & $\begin{array}{l}\text { POWER OF } \\
\text { RESOURCES }\end{array}$ & $\begin{array}{l}\text { POWER OF } \\
\text { PROCESSES }\end{array}$ & $\begin{array}{l}\text { POWER OF } \\
\text { MEANING }\end{array}$ \\
\hline $\begin{array}{l}\text { IMPACT ON } \\
\text { ACTIONS }\end{array}$ & $\begin{array}{l}\text { principles of } \\
\text { behaviour } \\
\text { modification are } \\
\text { used to influence } \\
\text { specific actions }\end{array}$ & $\begin{array}{l}\text { confusion -- focus } \\
\text { on process without } \\
\text { the support of } \\
\text { resource power to } \\
\text { direct behaviour }\end{array}$ & $\begin{array}{l}\text { confusion -- focus } \\
\text { on meaning without } \\
\text { the support of } \\
\text { resource power } \\
\text { makes it difficult to } \\
\text { influence specific } \\
\text { behaviour }\end{array}$ \\
\hline $\begin{array}{l}\text { IMPACT ON } \\
\text { AWARENESS }\end{array}$ & $\begin{array}{l}\text { inertia -- resource } \\
\text { power is } \\
\text { inadequate to } \\
\text { influence } \\
\text { awareness }\end{array}$ & $\begin{array}{l}\text { new awareness is } \\
\text { created through } \\
\text { the introduction } \\
\text { of new } \\
\text { participants, } \\
\text { agendas and } \\
\text { processes }\end{array}$ & $\begin{array}{l}\text { confusion -- focus } \\
\text { on meaning without } \\
\text { the support of } \\
\text { process power } \\
\text { makes it difficult to } \\
\text { translate } \\
\text { awareness into } \\
\text { behaviour }\end{array}$ \\
\hline $\begin{array}{l}\text { IMPACT ON } \\
\text { VALUES }\end{array}$ & $\begin{array}{l}\text { inertia -- resource } \\
\text { power is } \\
\text { inadequate to } \\
\text { influence values }\end{array}$ & $\begin{array}{l}\text { inertia -- process } \\
\text { power is } \\
\text { inadequate to } \\
\text { influence values }\end{array}$ & $\begin{array}{l}\text { strategic change } \\
\text { is legitimated } \\
\text { (given new } \\
\text { meaning) by } \\
\text { influencing } \\
\text { values and norms }\end{array}$ \\
\hline
\end{tabular}


Table 5.

Mobilizing and Targetting Power for Strategic Action at ELB

\begin{tabular}{|c|c|c|c|}
\hline $\begin{array}{l}\text { Power questions } \rightarrow \\
\text { Alignment } \\
\text { questions } \downarrow\end{array}$ & $\begin{array}{l}\text { How can I mobilize } \\
\text { resource power? }\end{array}$ & $\begin{array}{l}\text { How can I mobilize } \\
\text { process power? }\end{array}$ & $\begin{array}{l}\text { How can I mobilize } \\
\text { meaning power? }\end{array}$ \\
\hline $\begin{array}{l}\text { How do I want the } \\
\text { structure to } \\
\text { change? } \\
\text { Factories to } \\
\text { become } \\
\text { autonomous profit } \\
\text { centres. }\end{array}$ & $\begin{array}{l}\text { Five levels of } \\
\text { hierarchy between } \\
\text { factories and } \mathrm{HQ} \text { is } \\
\text { cut }\end{array}$ & $\begin{array}{l}\text { Factory directors } \\
\text { report directly to } \\
\text { CEO }\end{array}$ & $\begin{array}{l}\text { Factory managers } \\
\text { become known as } \\
\text { "Factory Directors" }\end{array}$ \\
\hline $\begin{array}{l}\text { How do I want the } \\
\text { systems to } \\
\text { change? } \\
\text { Development of } \\
\text { accounting } \\
\text { systems that track } \\
\text { new performance } \\
\text { ratios. }\end{array}$ & $\begin{array}{l}\text { Resources } \\
\text { allocated to } \\
\text { develop new } \\
\text { accounting } \\
\text { systems }\end{array}$ & $\begin{array}{l}\text { Payroll clerks in } \\
\text { each factory help } \\
\text { develop new } \\
\text { accounting } \\
\text { systems and report } \\
\text { directly to factory } \\
\text { director }\end{array}$ & $\begin{array}{l}\text { Payroll clerks } \\
\text { become } \\
\text { "Accounting } \\
\text { Managers" }\end{array}$ \\
\hline $\begin{array}{l}\text { How do I want the } \\
\text { people to change? } \\
\text { Factory managers } \\
\text { to take initiatives to } \\
\text { cut costs. }\end{array}$ & $\begin{array}{l}\text { Factories that fail } \\
\text { to meet } \\
\text { performance } \\
\text { criteria to be } \\
\text { rationalized }\end{array}$ & $\begin{array}{l}\text { Factory directors } \\
\text { given autonomy to } \\
\text { act as decision } \\
\text { makers at the local } \\
\text { level }\end{array}$ & $\begin{array}{l}\text { Factory directors } \\
\text { required to present } \\
\text { last year's } \\
\text { performance and } \\
\text { next year's plans to } \\
\mathrm{HQ} \text {, other factories } \\
\text { and middle } \\
\text { managers }\end{array}$ \\
\hline $\begin{array}{l}\text { How do I want the } \\
\text { culture to change? } \\
\text { Development of a } \\
\text { corporate identity } \\
\text { to offset local } \\
\text { autonomy. }\end{array}$ & $\begin{array}{l}\text { Part of bonus to be } \\
\text { linked to corporate } \\
\text { performance }\end{array}$ & $\begin{array}{l}\text { Factory directors } \\
\text { participate in } \\
\text { strategy making } \\
\text { process through } \\
\text { annual conference }\end{array}$ & $\begin{array}{l}\text { CEO visits } \\
\text { factories each year } \\
\text { to spread the } \\
\text { corporate word }\end{array}$ \\
\hline
\end{tabular}




\section{Bibliography}

Alvesson, M. and Willmott, H. (1992). "On the idea of emancipation in management and organization studies", Academy of Management Review, 17(3): 432-464.

Andrews, K.R. (1980), The Concept of Corporate Strategy, Homewood, Illinois: R.D. Irwin.

Bachrach, P. and Baratz, M.S. (1962). "The Two Faces of Power", American Political Science Review, 56, 947-52.

Baum, H.S. (1989). "Organizational Politics Against Organizational Culture: A Psychoanalytic Perspective", Human Resource Management, 28(2), 191-206, p.195.

Bowman, C. and Johnson, G. (1992). "Surfacing Competitive Strategies", European Management Journal, 10 (2), 210-219.

Brown, D. (1992). "Why Participative Management Won't Work Here", Management Review, 81(6), 42-46, 1992.

Burawoy, M. (1979) Manufacturing Consent. Chicago: Chicago University Press.

Chaffee, E.E. (1985). "Three Models of Strategy," Academy of Management Review, 10 (1), 89-98.

Chang, Richard Y. (1993). "When TQM Goes Nowhere", Training and Development, 47(1), 22-29.

Clegg, S. (1975). Power, Rule and Domination, London: Routledge and Kegan Paul.

Clegg, S. (1989). Frameworks of Power. London: Sage.

Crozier, M. (1964). The Bureaucratic Phenomenon, Chicago: University of Chicago Press.

Dahl, R. (1957). "The Concept of Power", Behavioural Science, 20, 201-215.

Deetz, S. (1992). Democracy in an Age of Corporate Colonization: Developments in Communication and the Politics of Everyday Life, Albany, NY: State University of New York. 
Eccles, R. and Nohria, N. (1993). Beyond the Hype, Cambridge, Mass: Harvard Business School.

Edelman, M. (1971). Politics as Symbolic Action. Chicago: Markham.

Edelman, M. (1977). Political Language. London: Academic Press.

Forester, J. (1989). Planning in the Face of Power. Berkely: University of California Press.

Foucault, M. (1979). Discipline and Punish: The Birth of the Prison, New York: Vintage Books, 1979.

Foucault, M. (1980). Power/Knowledge: Selected Interviews and Other Writings 19721977, (ed) C. Gordon, Brighton: Harvester Press.

Foucault, M. (1982). "The Subject and Power" in Dreyfus, H.L. and P. Rabinow. Michel Foucault: Beyond Structuralism and Hermeneutics, 208-226, Brighton: Harvester.

Fox, A. (1973). "Industrial Relations: A Social Critique of Pluralist Ideology", in J.Child (Ed.), Man and Organization, 185- 233, London: Allen and Unwin.

Frost, P.J. (1987). "Power, Politics and Influence". In Jablin, F.M., Putnam, L.L, Roberts, K.H., Porter L.W. (eds.) Handbook of Organizational Communications: An Interdisciplinary Perspective. London: Sage

Frost, PJ. and C.P. Egri. (1989). "The Political Process of Innovation", in Cummings, L.L. and B.M. Staw (eds.), Research in Organizational Behaviour, Greenwich, CT: JAI Press.

Fulmer, W.E. (1989). "Human Resource Management: The Right Hand of Strategic Implementation", Human Resource Planning, 12, (4), 1-11.

Giddens, A. (1979). Central Problems in Social Theory, London: Macmillan.

Gray, B. and Ariss, S.S. (1985). "Politics and Strategic Change Across Organizational Life Cycles", Academy of Management Review, 10(4), 707-723.

Hamel, G. and Prahalad, C.K. (1989). "Strategic Intent", Harvard Business Review, 67 (3), 63-76, May-June.

Hamel, Gary and Prahalad, C.K. (1993). "Strategy as Stretch and Leverage", Harvard Business Review, 71(2), 75-84. 
Harari, O. (1993). "Ten reasons why TQM doesn't work", Management Review, 82(1), 3338.

Hardy, C. (1985). Managing Organizational Closure, Aldershot, UK: Gower.

Hardy, C. (1994). Managing Strategic Action: Mobilizing Change, London: Sage.

Hardy, C. (1995). "Managing Strategic Change: Power, Paralysis and Perspective", Advances in Strategic Management, 12(B), 3-31.

Hardy, C. and Redivo, F. (1994). "Power and Organizational Development: A Framework for Organizational Change", Journal of General Management, 20(2), 1-13.

Hickson, D.J., Hinings, C.R., Lee, C.A., Schneck, R.E. and Pennings, J.M. (1971). "A Strategic Contingencies Theory of Intraorganizational Power," Administrative Science Quarterly, 16, 216-229.

Hrebiniak, L. G. (1990). "Implementing Strategy", Chief Executive, 57, 74-77.

Hurst, D.K. (1986) "Why Strategic Management is Bankrupt", Organizational Dynamics, 15, 5-27.

Huston, L.A. (1992). "Using Total Quality to Put Strategic Intent into Motion", Planning Review, 20(5), 21-23, 1992.

Hyman R. and Fryer, R.H. (1975). "Trade Unions: Sociological and Political Economy" in McKinlay, J.B. (ed.) Processing People. London: Holt, Rinehart and Winston.

Kaplan, Robert E. (1991). "Why Empowerment Often Fails." Executive Excellence, 8(12), 9.

Kiechel, W. (1982). "Corporate Strategies", Fortune, 106, 34-39.

Kizilos, P. (1990). "Crazy About Empowerment?" Training, 27, 12 47-56.

Knights, D. (1992). "Changing Spaces: The Disruptive Impact of a New Epistemological Location for the Study of Management", Academy of Management Review, 17(3), 514-36.

Knights, D. and Morgan, G. (1991). "Strategic Discourse and Subjectivity: Towards a Critical Analysis of Corporate Strategy in Organisations", Organisation Studies, 12 (3), 251-273. 
Kordupleski, R.E., Rust, R.T. and Zahhorik, A.J. (1993). "Why Improving Quality Doesn't Improve Quality (Or Whatever Happened to Marketing)", California Management Review, 36, 82-95.

Lorsch, J. (1986). "Managing Culture: The Invisible Barrier to Strategic Change", California Management Review, 28(2), 95-109.

Lukes, S. (1974). Power: A Radical View, London; New York: Macmillan.

MacMillan, I.C. (1978). Strategy Formulation: Political Concepts, St. Paul, Minnesota: West.

McPartlin, J.P. (1993). "Reengineering: Just Chasing Rainbows?" Information Week, February 1, 55.

Mechanic, D. (1962). "Sources of Power of Lower Participants in Complex Organizations," Administrative Science Quarterly, 7(3), 349-64.

Miles R.E. and Snow, C.C. (1978). Organizational Strategy, Structure and Process, New York: Harper and Row.

Mintzberg, H., and Waters, J.A. (1985). "Of Strategies, Deliberate and Emergent", Strategic Management Journal, 6, 257-272.

Mintzberg, H. (1993). "The Pitfalls of Strategic Planning", California Management Review, $5,32-47$.

Mintzberg, H. (1994). "The Fall and Rise of Strategic Planning", Harvard Business Review, January-February.

Narayanan, V.K. and Fahey, L. (1982). "The Micro-Politics of Strategy Formulation", Academy of Management Review, 7(1), 25-34.

Nord, W.R. and Jermier, J.M. (1992). "Critical Social Science for Managers? Promising and Perverse Possibilities", in Critical Management Studies, Mats Alvesson and Hugh Willmott, (eds.) London: Sage.

Pascale, R.T. (1990). "The Renewal Factor: Constructive Contention", The Planning Forum, 17(6), 4-13.

Peters, T.J. and Waterman, R.H. (1982). In Search of Excellence, New York: Harper and Row, 1982. 
Pettigrew, A.M. (1973). The Politics of Organizational Decision Making, London: Tavistock.

Pettigrew, A.M. (1977). "Strategy Formulation as a Political Process", International Studies of Management and Organization, 7(2), 78-87.

;

Pettigrew, A.M. (1979). "On Studying Organizational Cultures", Administrative Science Quarterly, 24, 570-81.

Pettigrew, A.M. (1985). The Awakening Giant: Continuity and Change in Imperial Chemical Industries, Oxford: Basil Blackwell.

Pfeffer, J. (1981). Power in organizations, Marshfield, Mass: Pitman.

Pfeffer, J. (1992). "Understanding Power in Organizations", California Management Review, 34(2), 29-50.

Prahalad, C.K. and G.H. (1990). "The Core Competence of the Corporation", Harvard Business Review, 68(3), 79-91.

Ranson, S., Hinings, C.R. and Greenwood, R. (1980). "The Structuring of Organizational Structure", Administrative Science Quarterly, 25 (1), 1-14.

Roberts, J. (1990). "Strategy and Accounting in a UK Conglomerate", Accounting, Organizations and Society, 15(1/2), 107-126.

Schwenk, C.R. (1989). "Linking Cognitive, Organizational and Political Factors in Explaining Strategic Change", Journal of Management Studies, 26(2), 177-188.

Scott, W.G. and Hart, D.K. (1979). Organizational America, Boston: Houghton Mifflin.

Thompson, J.D. (1956). "Authority and Power in Identical Organizations", American Journal of Sociology, 62, 290-301.

Walsh, K., Hinings, R., Greenwood, R., and Ranson, S. (1981). "Power and Advantage in Organizations", Organization Studies, 2(2), 131-152, p.141.

Want, J.W. (1993). "Managing Radical Change", Journal of Business Strategy, 15 (3), $20-$ 30 . 
Webster, J.L., Reif, W.E. and Bracker, J.S. (1989). "The Manager's Guide to Strategic Planning Tools and Techniques", Planning Review, 17 (6), 4-13, 1989.

Westley, F. (1990). "The Eye of the Needle: Cultural and Personal Transformation in a Traditional Organization", Human Relations, 43(3), 273-293. 


\section{Notes}

1. This example is drawn from Westley (1990) and also appears in Hardy (1994).

2. This example is drawn from Roberts (1990) and also appears in Hardy (1994). 


\section{University Library}

\section{- M M I N E R VA A gateway to Melbourne's research publications}

Minerva Access is the Institutional Repository of The University of Melbourne

Author/s:

Hardy, C

Title:

Understanding power: Bringing about strategic change

Date:

1996-01-01

Citation:

Hardy, C. (1996). Understanding power: Bringing about strategic change. British Journal of Management, 7 (SPEC. ISS.), pp.S3-S16. https://doi.org/10.1111/ j.1467-8551.1996.tb00144.x.

Persistent Link:

http://hdl.handle.net/11343/116095 